\title{
PENGARUH SKEPTISISME PROFESIONAL, KOMPETENSI, DAN INDEPENDENSI AUDITOR TERHADAP KUALITAS PEMERIKSAAN DALAM PENGAWASAN KEUANGAN DAERAH DENGAN KEPATUHAN PADA KODE ETIK SEBAGAI VARIABEL MODERATING
}

\author{
Feibe Maria Turangan \\ David Paul .E. Saerang \\ Jullie. J. Sondakh \\ (Email: feibemaria.turangan@gmail.com)
}

\begin{abstract}
ASTRACT
Auditing quality is a complex issue as it deals with so many interfering factors and depends on the viewpoints of each party.

The objective of this research is to find out the influence of professional scepticism, competence, independence on auditing quality with complience to the code of ethics as moderating variable at Inspectorate of North Sulawesi Province. The respondents are all the 67 internal auditors Inspectorate of North Sulawesi Province.

Inferential statistic has been multiple linear regression analysis (multiple regression) and Moderated Regression Anlyisis (MRA). The results show that professional scepticism have a significant influencing on auditing quality, competence has no significant influencing on auditing quality, independence have a significant influencing on auditing quality, complience to the code of ethics have a significant influencing on auditing quality, professional scepticism is moderated by complience to the code of ethics has no influencing on auditing quality, competence is moderated by complience to the code of ethics has no influencing on auditing quality and independence is moderated by complience to the code of ethics has no influencing on auditing quality.

Keywords : Professional skepticism, competence, independence, complience to the code of ethics, auditing quality.
\end{abstract}

\subsection{Latar Belakang}

\section{PENDAHULUAN}

Mewujudkan pemerintah yang baik diperlukan komitmen dari semua pihak (pemerintah dan masyarakat). Wujud Kepemerintahan Yang Baik (good governance) adalah penyelenggaraan negara yang solid, bertanggung jawab, efektif dan efisien dengan mensinergikan interaksi yang konstruktif diantara domein domein Negara (Dasar-dasar Good Governance oleh annajwa.blogger). Terdapat tiga aspek utama yang menurut Mardiasmo dapat mendukung terciptanya good governance, yaitu pengawasan, pengendalian, dan pemeriksaan.

Peraturan Menteri Dalam Negeri No 64 Tahun 2007 pasal 3 menyatakan bahwa Inspektorat provinsi mempunyai tugas melakukan pengawasan terhadap pelaksanaan urusan pemerintahan di daerah provinsi, pelaksanaan pembinaan atas penyelenggaraan pemerintahan daerah kabupaten/kota dan pelaksanaan urusan pemerintahan di daerah kabupaten/kota.

Namun pada kenyataannya hasil pemeriksaan yang dilaksanakan oleh aparat Inspektorat Provinsi Sulawesi Utara saat ini masih menjadi sorotan, dan memunculkan banyak pertanyaan. Hal ini dikarenakan masih banyaknya temuan audit yang tidak ditemukan atau dideteksi oleh aparat inspektorat sebagai auditor internal, akan tetapi ditemukan oleh auditor eksternal yaitu BPK.

Dari data yang ada dapat dibandingan jumlah temuan serta kerugian negara/daerah yang ditemukan oleh BPK-RI dan Inspektorat Provinsi Sulawesi Utara. Jumlah temuan yang diperoleh dari hasil pemeriksaan BPK-RI lebih besar daripada yang ditemukan oleh Inspektorat Provinsi Sulawesi Utara.

Salah satu penyebab nilai temuan kerugian daerah oleh BPK-RI lebih besar dibandingkan yang ditemukan oleh Inspektorat yaitu BPK-RI melaksanakan pemeriksaan setelah 1 tahun anggaran berakhir (post audit) sehingga semua penyimpangan akan lebih mudah terdeteksi, sedangkan Inspektorat Provinsi melaksanakan pemeriksaan pada saat kegiatan sementara 
berlangsung sehingga baru bisa memprediksi potensi-potensi penyimpangan. Selain itu kualitas audit Inspektorat Provinsi Sulawesi Utara turut memberikan andil yang besar dalam mendeteksi adanya kerugian daerah.

Dalam sektor publik, Government Accountability Office (GAO) dan Ikatan Akuntan Indonesia (IAI), memiliki pendapat yang sama tentang kualitas audit yaitu ketaatan terhadap standar profesi dalam arti audit dikatakan berkualitas jika memenuhi standar auditing dan standar pengendalian mutu.

Pentingnya standar bagi pelaksanaan audit juga dikemukakan oleh Pramono (2003) dalam tulisan Efendy (2010), dikatakan bahwa produk audit yang berkualitas hanya dapat dihasilkan oleh suatu proses audit yang sudah ditetapkan standarnya. Lebih lanjut dijelaskan bahwa proses audit dapat dikatakan telah memenuhi syarat quality assurance apabila proses yang dijalani tersebut telah sesuai dengan standar, antara lain: standar for the professional practice, internal audit charter, kode etik internal audit, kebijakan, tujuan, dan prosedur audit, serta rencana kerja audit.

Pernyataan standar umum pertama SPKN adalah: "Pemeriksa secara kolektif harus memiliki kecakapan profesional yang memadai untuk melaksanakan tugas pemeriksaan". Dengan Pernyataan Standar Pemeriksaan ini semua organisasi pemeriksa bertanggung jawab untuk memastikan bahwa setiap pemeriksaan dilaksanakan oleh para pemeriksa yang secara kolektif memiliki pengetahuan, keahlian, dan pengalaman yang dibutuhkan untuk melaksanakan tugas tersebut.

Pernyataan standar umum kedua SPKN adalah: "Dalam semua hal yang berkaitan dengan pekerjaan pemeriksaan, organisasi pemeriksa harus bebas dalam sikap mental dan penampilan dari gangguan pribadi, ekstern, dan organisasi yang dapat mempengaruhi independensinya".

Studi empiris dibeberapa daerah telah menunjukan bahwa kompetensi maupun independensi berpengaruh terhadap kualitas audit. Penelitian Darayasa dan Wisadha (2016) di Denpasar, Khairunnisa, et al (2013) pada BPKP Kalimantan Selatan, Safitri, et al, (2013) pada inspektorat daerah kabupaten se eks karesidenan banyumas, Marsellia, et al (2012) di Jakarta. Namun Riduwan, Suryono (2013) mendapat hasil yang berbeda pada saat melakukan penelitian di Inspektorat Kab. Gresik, Kab. Sidoarjo dan Kota Surabaya yakni kompetensi tidaklah berpengaruh terhadap kualitas hasil pemeriksaan. Juga Perdany dan Suranta (2013) yang berpendapat bahwa auditor di BPK-RI Yogyakarta masih ragu-ragu untuk memberitahukan kepada atasan apabila mereka mengalami gangguan independensi. Demikian pula Efendy, 2010 pada Inspektorat Kota Gorontalo, membuktikan bahwa independensi tidak berpengaruh signifikan terhadap kualitas audit.

Pernyataan standar umum ketiga SPKN adalah "Dalam pelaksanaan pemeriksaan serta penyusunan laporan hasil pemeriksaan, pemeriksa wajib menggunakan kemahiran profesionalnya secara cermat dan seksama".

Beberapa studi juga secara empiris mendukung akan pernyataan SPKN ketiga bahwa kemahiran profesional yang mencakup skeptisme profesional mempengaruhi hasil pemeriksaannya. Rahmatika Ananda (2014) dalam penelitiannya membuktikan bahwa skeptisme profesional berpengaruh signifikan positif terhadap kualitas audit. Demikian halnya dengan Safitri, Sularso, Restianto (2013), yang meneliti inspektorat daerah kabupaten se eks karesidenan banyumas. A.A.Kalau (2013) pada Inspektorat Kota Ambon, Adrian (2013) pada BPK RI perwakilan Riau, yang menunjukan pengaruh signifikan dari skeptisisme profesional terhadap kualitas pemeriksaan.

Pusdiklatwas BPKP,2008 menyatakan bahwa kepercayaan masyarakat dan pemerintah atas hasil kerja auditor ditentukan oleh keahlian, independensi serta integritas moral/ kejujuran para auditor dalam menjalankan pekerjaannya. Ketidakpercayaan masyarakat terhadap satu atau beberapa auditor dapat merendahkan martabat profesi auditor secara keseluruhan, sehingga dapat merugikan auditor lainnya.

Oleh karena itu organisasi auditor berkepentingan untuk mempunyai kode etik yang dibuat sebagai prinsip moral atau aturan perilaku yang mengatur hubungan antara auditor dengan auditan, antara auditor dengan auditor dan antara auditor dengan masyarakat.

Peraturan Menteri Dalam Negeri No. 28 Tahun 2007 tanggal 30 Mei 2007 tentang Norma Pengawasan dan Kode Etik Pejabat Pengawas Pemerintah dalam ketentuan umum pasal 1 point 2 menyebutkan kode etik pejabat pengawas pemerintah adalah seperangkat prinsip moral atau nilai 
yang dipergunakan oleh pejabat pengawas pemerintah sebagai pedoman tingkah laku dalam melaksanakan tugas pengawasan.

Studi empiris yang dilakukan Rahmatika Ananda (2014) pada BPKP perwakilan Sumatera Utara, Lubis (2009) pada Inspektorat Provinsi Sumatera Utara membuktikan bahwa kepatuhan pada kode etik berpengaruh signifikan positif terhadap kualitas audit. Disamping itu, beberapa peneliti menggunakan etika auditor sebagai pemoderasi antara kompetensi, independensi dengan kualitas audit dan memperoleh hasil rata-rata baik. Artinya kompetensi dan independensi yang berinteraksi dengan etika auditor menunjukan pengaruh positif walaupun ada pula yang berpengaruh negatif. (Darayasa dan Wisadha (2016) ; Riduwan, Suryono (2013) ; Khairunnisa, et al (2013) ; Marsellia, et al (2012).

Permenpan nomor 5 tahun 2008 tentang Standar APIP menegaskan "pelaksanaan audit harus mengacu pada standar audit, dan auditor wajib mematuhi kode etik_yang merupakan bagian yang tidak terpisahkan dari standar audit ini"'.

Uraian diatas menjadi alasan dan dasar dari penulis untuk menetapkan kepatuhan pada kode etik sebagai variabel yang dapat memoderasi pengaruh skeptisisme profesional, kompetensi dan indepensi terhadap kualitas pemeriksaan aparat Inspektorat Provinsi Sulawesi Utara.

\subsection{Rumusan Masalah}

Mengacu pada permasalahan yang ada, maka dapat dirumuskan permasalahan dalam bentuk pertanyaan:

a. Apakah Skeptisisme profesional aparat pengawasan berpengaruh terhadap kualitas pemeriksaan ?

b. Apakah kompetensi aparat pengawasan berpengaruh terhadap kualitas pemeriksaan ?

c. Apakah independensi dari aparat pengawasan berpengaruh terhadap kualitas

d. Apakah Kepatuhan pada Kode Etik aparat pengawasan berpengaruh terhadap kualitas pemeriksaan?

e. Apakah Skeptisme profesional yang dimoderasi oleh kepatuhan pada kode etik berpengaruh terhadap kualitas pemeriksaan

f. Apakah kompetensi yang dimoderasi oleh kepatuhan pada kode etik berpengaruh terhadap kualitas pemeriksaan

g. Apakah independensi yang dimoderasi oleh kepatuhan pada kode etik berpengaruh terhadap kualitas

\subsection{Landasan Teori \\ Teori Agensi}

Menurut teori ini hubungan antara pemilik sebagai principle dan manajer selaku agen pada hakikatnya sukar tercipta karena adanya kepentingan yang saling bertentangan (conflict of interst). Jensen dan Meckling (1976:5) menjelaskan hubungan keagenan sebagai

"agency relationship as a contract under which one or more persons (the principal(s)) engage another person (the agent) to perform some service on their behalf which involves delegating some decision making authority to the agent.

Karena itu diperlukan pihak ketiga yang independen yakni auditor untuk melakukan pemeriksaan terhadap laporan pertanggungjawaban / laporan keuangan yang dibuat oleh agen agar dapat lebih reliable (dapat lebih dipercaya). Dalam penelitian ini, teori agency dihubungkan dengan kualitas pemeriksaan yang dihasilkan oleh auditor. Auditor intern diharapkan menjadi penengah antara pihak agen dalam hal ini kepala daerah dan principal yakni SKPD yang akan mengurangi asimetris informasi antara kepala daerah dan SKPD.

\section{Teori Keutamaan}

Plato membedakan empat keutamaan paling utama yaitu kebijaksanaan, keberanian, sikap tau diri dan keadilan sebagai keutamaan yang mengimbangi keutamaan-keutamaan lain serta mempersatukannya. Sementara dalam Etika Nikomacheia, Aristoteles membahas sekurang- 
kurangnya sebelas keutamaan yaitu keberanian, penguasaan diri, kemurahan hati, kebesaran hati, budi luhur, harga diri, sikap lemah lembut, kejujuran, keberadaban, keadilan dan persahabatan. Keutamaan bukan dipahami sebagai lawan dari suatu sikap buruk, melainkan sebagai penengah antara dua hal ataupun sikap yang ekstrem.( Magnis-Suseno, 1997:39).

Menurut teori ini, auditor dituntut dalam menjalankan tugasnya diharapkan dapat memiliki sifat yang jujur dan penuh dengan kewajaran dengan cara tetap bersikap objektif dalam membuat berbagai keputusan audit. Untuk itu, auditor perlu mempertahankan independensi yang ada pada dirinya. Auditor juga diharapkan dapat menjaga kepercayaan yang diberikan kepadanya, serta bersikap ulet dalam melakukan proses audit hingga dapat menghasilkan kualitas audit yang baik. (Marsellia, et,al. 2012).

\section{Teori Egoisme}

Karena ada begitu banyak teori etika yang berkembang, maka secara garis besar Sukrisno (2009) membedakan teori etika tersebut dalam beberapa teori termasuk teori egoisme. Menurutnya, teori egoisme / egoism menjelaskan bahwa tindakan manusia dimotivasi oleh kepentingan diri sendiri (self-interest. Dalam teori ini, setiap perbuatan yang memberikan keuntungan akan dianggap sebagai perbuatan yang baik dan sebaliknya, perbuatan yang merugikan diri sendiri dianggap sebagai perbuatan yang buruk.

Dalam kenyataannya, auditor sebagai pihak ketiga yang independen dan bertugas menjadi penengah antara pihak agen dan principal, memiliki ego dalam dirinya sendiri. Sehingga, walaupun memiliki kompetensi dan independensi yang tinggi, terkadang auditor lupa akan etika profesi (kode etik) yang harus ia jaga dikarenakan adanya ego tersebut . (Marsellia,et,al. 2012).

Teori egoisme dalam penelitian ini berhubungan dengan kompetensi dan independensi yang dimiliki oleh auditor intern serta kode etik sebagai profesional auditor. Kompetensi dan independensi merupakan tuntutan mutlak yang harus dimikili seorang auditor dalam menjalankan tanggung jawab untuk menghasilkan pemeriksaan yang berkualitas.

\section{Teori Disonansi Kognitif}

Festinger (1957) dalam Kushasyandita( 2012), menyatakan hipotesis dasar dari teori disonansi kognitif yaitu bahwa adanya disonansi akan menimbulkan ketidaknyamanan psikologis, hal ini akan memotivasi seseorang untuk mengurangi disonansi tersebut dan mencapai konsonansi. Arti disonansi adalah adanya suatu inkonsistensi dan perasaan tidak suka yang mendorong orang untuk melakukan suatu tindakan untuk keluar dari ketidaknyamanan tersebut dengan dampakdampak yang tidak dapat diukur. Festinger menyatakan "cognition means any knowledge, opinion, or belief about the environment, about oneself or about one's behavior". Unsur kognisi adalah setiap pengetahuan, opini, atau apa saja yang dipercayai orang mengenai lingkungan, diri sendiri atau perilakunya.

Teori disonansi kognitif juga menjelaskan mengenai teori komunikasi yang membahas perasaan ketidaknyamanan seseorang yang diakibatkan oleh sikap, pemikiran, dan perilaku yang tidak konsisten dan memotivasi seseorang untuk mengambil langkah demi mengurangi ketidaknyamanan tersebut. Berbagai macam serangkaian situasi yang dialami auditor membuat auditor akan berusaha berperilaku selaras dengan perilaku yang seharusnya dilakukannya. Teori disonansi kognitif dalam penelitian ini berhubungan dengan skeptisisme profesional serta juga dapat menjelaskan mengenai kompetensi auditor.

\section{Pengawasan Keuangan Daerah}

Pengawasan atas penyelenggaraan pemerintahan diperlukan untuk menjamin agar pelaksanaan kegiatan pemerintahan berjalan sesuai dengan rencana dan sesuai dengan ketentuan peraturan perundang-undangan yang berlaku. Pengawasan terhadap Keuangan Daerah merupakan bagian dari tugas pokok inspektorat. Dan dalam pengawasan keuangan daerah, inspektorat melakukan pengawasan mulai dari perencanaan, pelaksanaan sampai pada pelaporan. Hal-hal penting yang menjadi objek pengawasan keuangan daerah adalah pelaksanaan APBD, penerimaan 
pendapatan daerah dan Badan Usaha Daerah, pengadaan barang/jasa serta pemeliharaan/penghapusan barang/jasa, penelitian dan penilaian laporan pajak-pajak pribadi, penyelesaian ganti rugi, serta inventarisasi dan penelitian kekayaan pejabat di lingkungan Pemda. Selain itu, pengawasan inspektorat juga meliputi pengawasan terhadap produk hukum dan kebijakan daerah termasuk didalamnya kebijakan keuangan, pelaksanaan penyelenggaraan pemerintahan daerah, dan pengawasan sumber daya manusia dalam hal ini kinerja pegawai.

\section{Kualitas Pemeriksaan}

De Angelo (1981:186) menyatakan bahwa:

The probability that a given auditor will discover a breach depends on the auditor's technological capabilities, the audit procedures employed on a given audit, the extent of sampling, etc. The conditional probability of reporting a discovered breach is a measure of an auditor's independence from a given client.

PermenPAN nomor PER/05/M.PAN/03/2008 mengatur bahwa pengukuran kualitas audit atas laporan keuangan, khususnya yang dilakukan oleh APIP, wajib menggunakan Standar Pemeriksaan Keuangan Negara (SPKN). Dalam lampiran 3 SPKN disebutkan:

"Besarnya manfaat yang diperoleh dari pekerjaan pemeriksaan tidak terletak pada temuan pemeriksaan yang dilaporkan atau rekomendasi yang dibuat, tetapi terletak pada efektivitas penyelesaian yang ditempuh oleh entitas yang diperiksa. Manajemen entitas yang diperiksa bertanggung jawab untuk menindaklanjuti rekomendasi serta menciptakan dan memelihara suatu proses dan sistem informasi untuk memantau status tindak lanjut atas rekomendasi pemeriksa dimaksud. Jika manajemen tidak memiliki cara semacam itu, pemeriksa wajib merekomendasikan agar manajemen memantau status tindak lanjut atas rekomendasi pemeriksa. Perhatian secara terus-menerus terhadap temuan pemeriksaan yang material beserta rekomendasinya dapat membantu pemeriksa untuk menjamin terwujudnya manfaat pemeriksaan yang dilakukan" (paragraf 17)".

Kualitas ini harus dibangun sejak awal pelaksanaan audit hingga pelaporan dan pemberian rekomendasi. Karena itu, indikator yang tepat digunakan untuk mengukur kualitas hasil audit antara lain kualitas proses, apakah audit dilakukan dengan cermat, sesuai prosedur, sambil terus mempertahankan sikap skeptis. (Efendy, 2010).

\section{Skeptisisme Profesional}

Dalam Standar Profesional Akuntan Publik (SPAP), Standar Audit (SA) paragraf 13 huruf 1, Skeptisisme professional adalah suatu sikap yang mencakup suatu pikiran yang selalu mempertanyakan, waspada terhadap kondisi yang dapat mengindikasikan kemungkinan kesalahan penyajian, baik yang disebabkan oleh kecurangan maupun kesalahan, dan suatu penilaian penting atas bukti audit. Skeptisisme profesional mencakup kewaspadaan terhadap hal-hal berikut ini:

1. Bukti audit yang bertentangan dengan bukti audit lain yang diperoleh.

2. Keadaan yang mengindikasikan adanya kemungkinan kecurangan.

3. Kondisi yang menyarankan perlunya prosedur yang disyaratkan oleh SA (Standar Audit).

4. Informasi yang menimbulkan pertanyaan tentang keandalan dokumen dan tanggapan terhadap permintaan keterangan yang digunakan sebagai bukti audit.

Secara khusus dalam audit, Standar Profesional Akuntan Publik (IAPI, 2011) menjelaskan bahwa skeptisisme profesional adalah sikap yang selalu mempertanyakan dan melakukan evaluasi bukti audit secara kritis. Pengertian serupa dipaparkan dalam International Standards on Auditing (IAASB, 2009), skeptisisme profesional adalah sikap yang meliputi pikiran yang selalu bertanyatanya (questioning mind), waspada (alert) terhadap kondisi dan keadaan yang mengindikasikan adanya kemungkinan salah saji material yang disebabkan oleh kesalahan atau kesengajaan (fraud), dan penilaian (assessment) bukti-bukti audit secara kritis. Konsep skeptisisme profesional yang tercermin dalam standar tersebut adalah sikap selalu bertanya-tanya, waspada, dan kritis dalam melaksanakan seluruh proses audit. (http://e-journal.uajy.ac.id). 


\section{Kompetensi}

Dalam standar audit APIP disebutkan bahwa audit harus dilaksanakan oleh orang yang memiliki keahlian dan pelatihan teknis cukup sebagai auditor. Dengan demikian, auditor belum memenuhi persyaratan jika ia tidak memiliki pendidikan dan pengalaman yang memadai dalam bidang audit. Dalam audit pemerintahan, auditor dituntut untuk memiliki dan meningkatkan kemampuan atau keahlian bukan hanya dalam metode dan teknik audit, akan tetapi segala hal yang menyangkut pemerintahan seperti organisasi, fungsi, program, dan kegiatan pemerintah.

Peraturan Kepala BPKP nomor 211 tahun 2010 tentang Standar Kompetensi Auditor menjelaskan ukuran kemampuan minimal yang harus dimiliki auditor yang mencakup aspek pengetahuan (knowledge), ketrampilan/keahlian (skill), dan sikap prilaku (attitude) untuk dapat melakukan tugas-tugas dalam jabatan fungsional auditor dengan hasil baik. Terdapat unsur-unsur kompetensi yang harus dimiliki oleh seorang auditor ahli yakni: Kompetensi inti, Kompetensi Pendukung dan Kompetensi Manajerial.

\section{Independensi}

Seorang auditor yang independen memiliki kebebasan yang cukup untuk melakukan audit yang andal, meskipun independensi yang sifatnya mutlak tidak mungkin dimiliki, auditor tetap harus memelihara independensinya untuk menjaga tingkat kepercayaan pengguna atas laporan yang dibuatnya. Boynton, dkk (2001:103) menyatakan bahwa seorang auditor harus bersikap independen baik dalam kenyataan maupun dalam penampilan pada saat melaksanakan audit atau jasa atestasi lainnya. Independensi dalam kenyataan (independence in fact) mengandung arti bahwa auditor harus mempunyai kejujuran dalam mempertimbangkan semua fakta yang ditemuinya dalam audit. Sementara independensi dalam penampilan (independence in appearance) berarti bahwa auditor harus memiliki independensi dari sudut pandang pihak lain yang mengetahui informasi yang terkait dengan diri auditor sehubungan dengan pelaksanaan audit. (Rahayu, 2013).
Menurut
Peraturan
Menteri
Negara
Pendayagunaan
Aparatur Negara No.PER/05/M.PAN/03/2008 tanggal 31 Maret 2008 Auditor harus memiliki sikap netral dan tidak bias serta menghindari konflik kepentingan dalam merencanakan dan melaporkan pekerjaan yang dilakukannya. Disamping itu jika independensi atau obyektifitasnya terganggu, baik secara faktual maupun penampilan, maka gangguan tersebut harus dilaporkan kepada pimpinan APIP.

\section{Kepatuhan pada Kode Etik}

Kode Etik dapat diartikan sebagai pola aturan, tata cara, tanda, pedoman etis dalam melakukan suatu kegiatan atau pekerjaan. Kode etik merupakan pola aturan atau tata cara sebagai pedoman berperilaku. Tujuan kode etik agar profesional memberikan jasa sebaik-baiknya kepada pemakai atau nasabahnya. Adanya kode etik akan melindungi perbuatan yang tidak profesional.

Kode Etik Auditor Intern Pemerintah Indonesia yang diterbitkan AAIPI( Asosiasi Auditor Intern Pemerintah Indonesia) dengan nomor S-01/AAIPI/3/2014 mengatur tentang prinsip etika yang diharapkan dapat diterapkan dan ditegakkan oleh auditor intern yakni prinsip Intergritas, Objektivitas, Kerahasiaan, Kompetensi, Akuntabel dan Perilaku Profesional.

Selanjutnya Peraturan Menteri Negara Pendayagunaan Aparatur Negara nomor PER/05/M.PAN/03/2008, menyatakan pelaksanaan audit harus mengacu kepada standar audit, dan auditor wajib mematuhi kode etik yang merupakan bagian yang tak terpisahkan dari standar audit. Selanjutnya menurut Perilaku profesional, Kode etik dibuat bertujuan untuk mengatur hubungan antara, lembaga dan organisasinya, sesamapejabat pengawas pemerintah, pihak yang diawasi, pihak lain yang terkait dan masyarakat.

Kode Etik Pejabat Pengawas Pemerintah adalah seperangkat prinsip moral atau nilai yang dipergunakan oleh pejabat pengawas pemerintah sebagai pedoman tingkah laku dalam melaksanakan tugas pengawasan, juga merupakan landasan etika yang harus dipahami dan dilaksanakan oleh setiap pejabat pengawas dalam melaksanakan tanggung jawabnya. 


\section{Hubungan Skeptisisme Profesional dengan Kualitas Pemeriksaan}

Skeptisisme profesional sangat diperlukan untuk meningkatkan kualitas audit, karena dengan bersikap skeptis, auditor akan lebih berinisiatif untuk mencari informasi lebih lanjut dari manajemen mengenai keputusan-keputusan akuntansi yang diambil, dan menilai kinerjanya sendiri dalam menggali bukti-bukti audit yang mendukung keputusan-keputusan yang diambil oleh manajemen tersebut (Financial Reporting Council, 2010).

Penelitian Safitri, et al (2013), pada inspektorat daerah kabupaten se eks karesidenan banyumas membuktikan bahwa secara signifikan skeptisisme profesional mempengaruhi kualitas pemeriksaan. Demikian juga penelitian Ananda (2014) pada BPKP Perwakilan Sumatera Utara bahwa skeptisme profesional berpengaruh signifikan positif terhadap kualitas audit. Penelitian yang dilakukan oleh A.Kalau (2013) dan Adrian (2013) juga menunjukan hasil yang sama yaitu adanya pengaruh signifikan antara skeptisisme profesional terhadap kualitas pemeriksaan. Berbeda dengan Nandari dan Latrini, 2015 pada beberapa KAP di Bali menunjukan sikap skeptis tidak berpengaruh secara signifikan terhadap kualitas audit.

Dari beberapa penelitian yang ada, sikap skeptisisme profesional menjadi hal yang penting untuk mendapatkan kualitas audit yang baik. Tetapi skeptisisme juga tergantung dari pengalaman menjadi auditor. Sikap skeptis antar auditor senior dan junior sangat mempengaruhi kualitas audit yang dihasilkan.

\section{Hubungan Kompetensi dengan Kualitas Pemeriksaan}

Pernyataan standar umum pertama SPKN adalah: "Pemeriksa secara kolektif harus memiliki kecakapan profesional yang memadai untuk melaksanakan tugas pemeriksaan". Lebih lanjut, Arens, et al (2014) menyatakan bahwa auditor wajib memiliki kompetensi dan kapabilitas yang layak untuk melaksanakan audit. Standar umum ini biasanya diinterpretasikan sebagai keharusan bagi auditor untuk memiliki pendidikan formal di bidang auditing dan akuntansi, pengalaman praktik yang memadai serta mengikuti pendidikan profesional yang berkelanjutan.

Mufidah, 2015 dalam penelitiannya menunjukkan bahwa kompetensi berpengaruh signifikan terhadap kualitas hasil pemeriksaan. Berbeda dengan penelitian Riduwan, Suryono (2013) membuktikan bahwa tidak ada pengaruh signifikan antara kompetensi terhadap kualitas audit. Selanjutnya, studi empiris Priyansari, Natalistyo pada BPKP Perwakilan Jawa Tengah menunjukkan bahwa kompetensi tidak berpengaruh secara parsial terhadap kualitas audit

Dari penelitian sebelum dapat dipahami bahwa kompetensi sangat mendukung auditor dalam melakukan pengawasan untuk mendapatkan hasil yang baik. Tapi kurangnya pengembangan diri auditor lewat pendidikan dan pelatihan menyebabkan rendahnya kemampuan auditor dalam melakukan audit. Hal inilah yang membuat kompetensi tidak mempengaruhi kualitas pemeriksaan pada beberapa penelitian sebelumnya.

\section{Hubungan Independensi dengan Kualitas Pemeriksaan}

Menurut Arens.et.el. 2014, kode perilaku AICPA dan IESBA mendefinisikan independensi sebagai hal yang terdiri dari dua komponen: 1)Independensi dalam berpikir (independence in mind) dan 2)Independensi dalam penampilan (independence in apperance).

Pernyataan standar umum kedua Standar Pemeriksaan Keuangan Negara (SPKN) adalah: "Dalam semua hal yang berkaitan dengan pekerjaan pemeriksaan, organisasi pemeriksa harus bebas dalam sikap mental dan penampilan dari gangguan pribadi, ekstern, dan organisasi yang dapat mempengaruhi independensinya".

Menurut Peraturan Menteri Negara Pendayagunaan Aparatur Negara No.PER/05/M.PAN/03/2008 tanggal 31 Maret 2008 Auditor harus memiliki sikap netral dan tidak bias serta menghindari konflik kepentingan dalam merencanakan dan melaporkan pekerjaan yang dilakukannya.

Studi empiris Priyansari, Natalistyo, 2015 menunjukkan bahwa independensi berpengaruh secara parsial terhadap kualitas audit di BPKP Perwakilan Provinsi Jawa Tengah karena auditor memiliki sikap mental yang bebas dari pengaruh, tidak dikendalikan oleh pihak lain, tidak 
tergantung pada orang lain. Berbeda dengan hasil penelitian Mufidah, 2015 yang menunjukkan bahwa independensi tidak berpengaruh signifikan terhadap kualitas hasil pemeriksaan. Selanjutnya penelitian yang dilakukan Nandari, Latrini, 2015 membuktikan bahwa independensi auditor tidak memiliki pengaruh secara signifikan terhadap kualitas audit.

Dari penelitian yang ada dapat dipahami betapa pentingnya independensi seorang auditor untuk menunjang kualitas pemeriksaan. Tetapi kendala terbesar yang dihadapi adalah hubungan yang terjalin antara auditor dan klien yang membuat independensi auditor terganggu dan menyebabkan rendahnya kualitas audit yang dihasilkan.

\section{Hubungan Kepatuhan pada kode etik (sebagai variabel pemoderasi) dengan Kualitas Pemeriksaan}

Etika (ethics) secara garis besar dapat didefinisikan sebagai serangkaian prinsip atau nilai moral. Perilaku etis sangat diperlukan oleh masyarakat agar dapat berfungsi secara teratur. Karena itu etika diargumentasikan sebagai perekat yang dapat mengikat anggota masyarakat. Kebutuhan akan etika dalam masyarakat cukup penting, sehingga banyak nilai etika yang umum dimasukkan dalam undang-undang. (Arens.et.el. 2014:90).

Kepercayaan masyarakat dan pemerintah atas hasil kerja auditor ditentukan oleh keahlian, independensi serta integritas moral/kejujuran para auditor dalam menjalankan pekerjaannya. Ketidakpercayaan masyarakat terhadap satu atau beberapa auditor dapat merendahkan martabat profesi auditor secara keseluruhan, sehingga dapat merugikan auditor lainnya. (Ananda, 2014).

Hasil penelitian Priyansari, Natalistyo, 2015 menunjukkan bahwa etika auditor berpengaruh secara parsial terhadap kualitas audit di Badan BPKP Perwakilan Provinsi Jawa Tengah. Lubis (2009) dan Ananda, (2014) juga menunjukan hasil yang sama bahwa kepatuhan pada kode etik berpengaruh signifikan positif terhadap kualitas audit pemerintah. Sehingga semakin tinggi sikap kepatuhan pada kode etik maka semakin baik juga kualitas audit.

Seorang auditor harus memiliki sikap kepatuhan pada kode etik maka dengan menerapkan sikap tersebut auditor akan mampu menjaga perilaku etisnya dan dapat memenuhi prinsip-prinsip kerja yang akuntabel dengan kinerja yang optimal dalam pelasanaan dalam pelaksanaan audit. Semakin tinggi sikap kepatuhan pada kode etik auditor maka akan semakin tinggi juga kepercayaan masyarakat atas kualitas auditor yang dihasilkan.

\section{Kerangka Konseptual Penelitian}

\section{KERANGKA KONSEPTUAL}

\section{Pengaruh Skeptisisme Profesional, Kompetensi dan Independensi Aparat Inspektorat dalam Pengawasan Keuangan Daerah dengan Kepatuhan Kode Etik sebagai Variabel Moderating.}

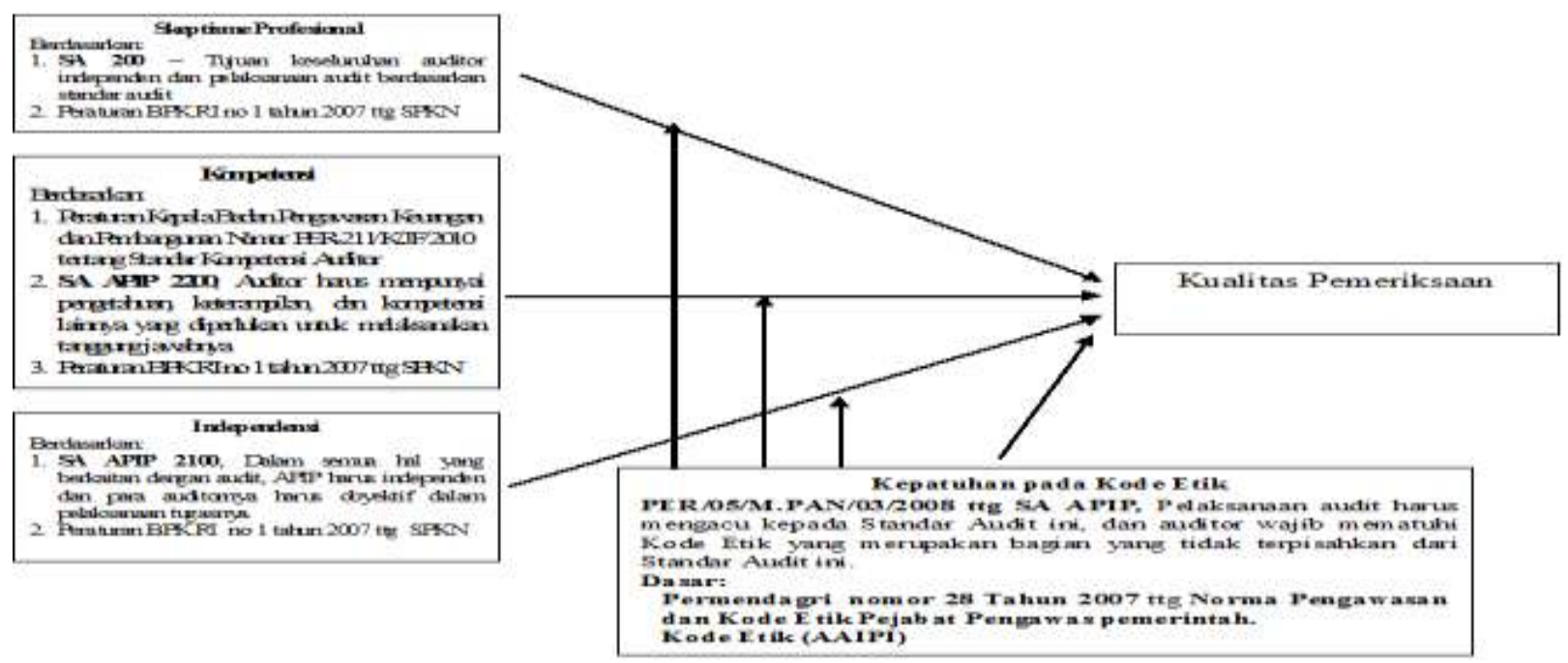




\section{Hipotesis Penelitian}

Berdasarkan tinjauan terhadap teori yang ada dan hasil penelitian sebelumnya, maka hipotesis penelitian ini adalah:

$\mathrm{Ha}_{1}$ : Skeptisme profesional berpengaruh terhadap kualitas pemeriksaan dalam pengawasan keuangan daerah.

$\mathrm{Ha}_{2}$ : kompetensi berpengaruh terhadap kualitas pemeriksaan aparat dalam pengawasan keuangan daerah

$\mathrm{Ha}_{3}$ : independensi berpengaruh terhadap kualitas pemeriksaan dalam pengawasan keuangan daerah

$\mathrm{Ha}_{4}$ : kepatuhan pada kode etik berpengaruh terhadap kualitas pemeriksaan dalam pengawasan keuangan daerah.

$\mathrm{Ha}_{5}$ : Skeptisisme profesional yang dimoderasi kepatuhan pada kode etik berpengaruh terhadap kualitas pemeriksaan dalam pengawasan keuangan daerah.

$\mathrm{Ha}_{6}$ : Kompetensi yang dimoderasi kepatuhan pada kode etik berpengaruh terhadap kualitas pemeriksaan dalam pengawasan keuangan daerah.

$\mathrm{Ha}_{7}$ : Independensi yang dimoderasi kepatuhan pada kode etik berpengaruh terhadap kualitas pemeriksaan dalam pengawasan keuangan daerah.

\section{Jenis Penelitian, dan Metode Pengumpulan Data}

\section{METODE PENELITIAN}

Data yang digunakan dalam penelitian ini adalah data primer. Data primer diperoleh dengan menggunakan daftar pertanyaan (kuesioner) yang telah terstruktur dengan tujuan untuk mengumpulkan informasi dari auditor pada Inspekorat Provinsi Sulawesi Utara sebagai responden dalam penelitian ini. Populasi dalam penelitian ini adalah seluruh aparat pengawasan Inspektorat Provinsi Sulawesi Utara yang ikut dalam tugas pemeriksaan. Jumlah kuesioner yang dibagikan kepada responden adalah sebanyak jumlah populasi yaitu 75 kuesioner.

\section{Variabel Penelitian dan Definisi Operasional Variabel}

\section{Kualitas Pemeriksaan}

Melaksanakan tugas pokok dan fungsi (tupoksi), menyediakan kerangka kerja pelaksanaan kegiatan audit, melaksanakan perencanaan, koordinasi dan penilaian efektifitas tindak lanjut audit, konsistensi laporan audit, dan mengikuti mengikuti standar audit. (Permenpan 5 thn 2008).

Instrumen yang digunakan untuk mengukur kualitas pemeriksaan ini diadopsi dari penelitian Perdany dan Suranta (2012), Effendy (2010).

\section{Skeptisisme profesional}

Kemahiran profesional menuntut pemeriksa untuk melaksanakan skeptisme profesional, yaitu sikap yang mencakup pikiran yang selalu mempertanyakan dan melakukan evaluasi secara kritis terhadap bukti pemeriksaan. Instrumen yang digunakan untuk mengukur skeptisisme profesional ini diadopsi dari penelitian Adrian (2013) dan Hasanah (2010) dengan beberapa modifikasi berdasarkan SPKN.

\section{Kompetensi Auditor}

Kompetensi dalam pengauditan merupakan pengetahuan, keahlian, dan pengalaman yang dibutuhkan auditor untuk dapat melakukan audit secara objektif, cermat dan seksama. Instrumen yang digunakan untuk mengukur kompetensi ini adalah unsur-unsur kompetensi yang termuat dalam Peraturan BPKP no 211 tahun 2010 tentang Standar kompetensi auditor.

\section{Independensi}


Independensi dalam pengauditan merupakan penggunaan cara pandang yang tidak bias dalam pelaksanaan pengujian audit, evaluasi hasil pengujian tersebut, dan pelaporan hasil temuan audit.

Instrumen yang digunakan untuk mengukur independensi ini diadopsi dari penelitian Effendy (2010), Perdany dan Suranta (2012)

\section{Kepatuhan pada Kode Etik}

Kepatuhan pada kode etik dalam penelitian ini adalah auditor harus mematuhi kode etik yang ditetapkan. Pelaksanaan audit harus mengacu kepada standar audit, dan auditor wajib mematuhi kode etik yang merupakan bagian yang tidak terpisahkan dari standar audit.

Instrumen yang digunakan untuk mengukur kepatuhan pada kode etik ini seperti yang digunakan dalam penelitian Lubis (2009) dan di modifikasi oleh penulis berdasarkan Permendagri 28 tahun 2007 tentang Norma Pengawasan dan Kode Etik Pejabat Pengawas Pemerintah serta kode etik yang dikeluarkan oleh AAIPI no. S-01/AAIPI/3/2014.

\section{Instrumen Penelitian}

Variable-variabel yang telah dijabarkan kedalam operasionalisasi variabel akan disusun menjadi kuesioner dalam bentuk pertanyaan dan pernyataan. Variabel skeptisisme profesional diujikan melalui 13 pernyataan dan pertanyaan; variabel kompetensi 24 pertanyaan dan pernyataan; variabel independensi 12 pernyataan dan pertanyaan; variabel kepatuhan pada kode etik 25 pernyataan dan pertanyaan dan variabel kualitas pemeriksaan 8 pertanyaan dan pertanyaan. Skala yang digunakan dalam penelitian ini adalah skala Likert.

\section{Regresi Berganda}

Pengujian hipotesis dalam penelitian ini menggunakan metode regresi berganda untuk mengetahui ada tidaknya pengaruh skeptisisme profesional, independensi dan kompetensi auditor terhadap kualitas pemeriksaan. Model persamaan yang digunakan adalah:

$\mathrm{Y}=\alpha+\beta 1 \mathrm{X} 1+\beta 2 \mathrm{X} 2+\beta 3 \mathrm{X} 3+\beta 4 \mathrm{X} 4+\mathrm{e}$

Metode kedua yang digunakan adalah Moderated Regression Anlyisis (MRA). MRA merupakan aplikasi khusus regresi linier berganda, dimana dalam persamaan regresinya mengandung unsur interaksi atau perkalian dua atau lebih variabel independen (Liana, 2009).. Model persamaan ini adalah: $\mathrm{Y}=\alpha+\beta 1 \mathrm{X} 1+\beta 2 \mathrm{X} 2+\beta 3 \mathrm{X} 3+\beta 4 \mathrm{X} 4+\beta 5 \mathrm{X} 1 * \mathrm{X} 4+\beta 6 \mathrm{X} 2 * \mathrm{X} 4+\beta 7 \mathrm{X} 3 * \mathrm{X} 4+\mathrm{e}$

Penggunaan model ini seperti yang digambarkan Hayes. Andrew.F dalam bukunya Statistical Methods for Communication Science mengenai Moderated Multiple Regressions (2005:463). Dan pengujian dengan model ini menggunakan bantuan SPSS versi 18 dengan teknik pengujian mengikuti modul Moderated Multiple Regression oleh PSY 512: Advenced Statisties for Phychological and Behavioral Research 2.

\section{Deskriptif Data}

\section{HASIL PENELITIAN DAN PEMBAHASAN}

Saat pelaksanaan penelitian, hanya 68 orang auditor yang bersedia menjadi responden, yaitu 34 orang laki-laki dan 34 orang perempuan. Berdasarkan tingkat pendidikan, diketahui bahwa mayoritas responden berpendidikan S1 sebanyak 77,9\% dan S2 22,1\%. Selanjutnya ditinjau dari lamanya terlibat dalam pemeriksaan, 50\% responden masih terbilang baru yakni $\leq 5$ tahun, $6-10$ tahun sebanyak 12,5\%, 20,6\% untuk 11-15 tahun. 4,4\% untuk 16-20 tahun dan 1,5\% untuk responden $>20$ tahun. Tetapi hanya 67 responden yang dianalisis.

\section{Hasil Analisis Regresi \\ Koefisien Determinasi}

Berdasarkan tampilan output model summary, dapat dijelaskan sebagai berikut:

1. Untuk model 1 (satu) besarnya adjusted $R^{2}$ adalah 0,403 . Nilai ini dapat menjelaskan bahwa 40,3\% variasi kualitas audit dapat dijelaskan oleh variasi dari variabel skeptisisme profesional, 
kompetensi, independensi, kepatuhan pada kode etik dan sisanya 59,7\% dipengaruhi oleh variabel yang tidak teramati di luar model.

2. Sedangkan model 2 (dua) besarnya adjusted $R^{2}$ adalah 0,375 menjelaskan bahwa $37,5 \%$ variasi kualitas pemeiksaan dapat dijelaskan oleh interaksi skeptisisme profesional dengan kepatuhan pada kode etik, interaksi kompetensi dengan kepatuhan pada kode etik, dan interaksi independensi dengan kepatuhan pada kode etik. Sisanya adalah 62,5\% dipengaruhi oleh variabel yang tidak teramati di luar model.

\section{Uji Simultan (Uji f)}

Dari hasil pengujian terhadap uji simultan ANOVA atau F test seperti yang ditampilkan, diperoleh hasil sebagai berikut:

1. Model 1 (satu) nilai Fhitung sebesar 12.152 dengan signifikansi 0,000. Karena signifikansi jauh lebih kecil dari nilai signifikan 0,05, maka model regresi ini dapat digunakan untuk memprediksi kualitas audit. Jika nilai F dibandingkan dengan Fhitung maka dapat diketahui bahwa nilai Fhitung $(12,152)$ lebih besar dari nilai Ftabel $(1,4989)$.

2. Model 2 (dua) nilai Fhitung sebesar 6,666 dengan signifikansi 0,000. Karena signifikansi jauh lebih kecil dari nilai signifikan 0,05, maka model regresi MRA ini dapat digunakan untuk memprediksi kualitas audit. Jika nilai $\mathrm{F}$ dibandingkan dengan Fhitung maka dapat diketahui bahwa nilai Fhitung $(6,666)$ lebih besar dari nilai Ftabel $(1,4989)$.

\section{Uji Parsial (Uji t)}

Hasil uji t menunjukkan sebagai berikut:

1. Untuk Model 1, skeptisisme profesional (X1) memiliki nilai signifikan 0,012 , Independensi (X3) dengan nilai signifikan 0,017 dan Kepatuhan pada kode etik (X4) dengan nilai signifikan sebesar 0,005. Ketiga variabel tersebut menunjukan bahwa thitung lebih besar dari 1,997 (ttabel). Hal tersebut menunjukkan bahwa skeptisisme profesional, independensi dan kepatuhan pada kode etik berpengaruh signifikan terhadap kualitas audit. Sedangkan kompetensi (X2) dengan nilai signifikannya diatas nilai signifikansi 0,05 yakni 0,190 dengan thitung lebih kecil dari tabel yang menunjukan tidak ada pengaruh terhadap kualitas pemeriksaan.

2. Model 2 menunjukan bahwa interaksi skeptisisme profesional dengan kepatuhan pada kode etik memiliki nilai signifikan 0,871, interaksi kompetensi dengan kepatuhan pada kode etik 0,827 dan interaksi independensi dengan kode etik 0,707. Hal ini membuktikan bahwa interaksi ketiga variabel independen dengan kepatuhan pada kode etik tidak mempunyai pengaruh yang signifikan terhadap kualitas pemeriksaan karena ketiganya bukan variabel moderat.

Dari hasil pengujian statistik diatas, maka berdasarkan hipotesa-hipotesa yang telah disusun dalam penelitian ini, dapat dijelaskan sebagai berikut:

a. Hasil pengujian Skeptisisme profesional (X1), Nilai signifikan 0,012 dibawah nilai signifikansi 0,05 . Nilai koefisien regresi adalah 0,552 dan nilai thitung 2,599, ttabel dengan nilai sebesar 1,997 , maka Ha1 diterima.

b. Hasil pengujian kompetensi (X2), nilai koefisien regresi adalah 0,070 dan nilai thitung 1,326 lebih kecil dibanding tabel 1,997 . Nilai koefisien regresi ini tidak signifikan pada tingkat signifikansi 0,05 dengan sig sebesar 0,190 maka Ha2 ditolak.

c. Hasil pengujian independensi (X3), nilai signifikan 0,017 dibawah nilai kepercayaan 0,05. Nilai koefisien regresi adalah 0,178 dan nilai thitung 2,451 dan ttabel 1,997 maka Ha3 diterima.

d. Hasil pengujian kepatuhan pada kode etik (X4), nilai koefisien regresi variabel 0,422 dan nilai thitung 2,948. Nilai koefisien regresi ini signifikan ada tingkat signifikansi 0,05 dengan sig sebesar 0,005. Jika dibanding dengan ttabel 1,997 menunjukan thitung lebih besar nilainya dari ttabel maka Ha4 diterima.

e. Nilai koefisien regresi interaksi skeptisisme profesional dan kepatuhan pada kode etik adalah 0,106. Nilai signifikan 0,871 lebih tinggi dari tingkat signifikansi 0,05 . Hasil perhitungan nilai thitung sebesar $-0,163<$ (lebih kecil) ttabel 1,99 maka Ha5 ditolak. 
f. Nilai koefisien regresi interaksi skeptisisme profesional dan kepatuhan pada kode etik adalah 0,045. Nilai signifikan 0,827 dengan signifikansi 0,05. Hasil perhitungan nilai thitung sebesar 0,219 lebih kecil dari ttabel 1,997 maka Ha6 ditolak.

g. Nilai koefisien regresi interaksi skeptisisme profesional dan kepatuhan pada kode etik adalah 0,305. Nilai signifikan 0,707 pada tingkat signifikansi 0,05 . Hasil perhitungan nilai thitung sebesar-0,378 lebih kecil dari ttabel 1,997 maka Ha7 ditolak.

\section{Pembahasan \\ Pengaruh Skeptisisme Profesional Terhadap Kualitas Pemeriksaan}

Hasil pengujian statistik menunjukkan bahwa skeptisisme profesional berpengaruh positif dan signifikan terhadap kualitas pemeriksaan. Hasil penelitian ini mendukung teori yang diungkapkan oleh Tuanakotta (2011:94) yang menyatakan, sikap skeptisme profesional auditor akan mempengaruhi perilaku sikap skeptismenya dan pada akhirnya akan meningkatkan kualitas audit.

Hasil pengujian hipotesis ini sejalan dengan Ananda (2014) yang menemukan data empiris bahwa skeptisme profesional berpengaruh signifikan positif terhadap kualitas audit. Artinya, semakin tinggi skeptisme profesional maka akan semakin baik pula kualitas audit pemerintah. Hasil ini juga sama dengan penelitian Safitri, Sularso, Restianto (2013) yang menemukan bukti bahwa skeptisisme berpengaruh signifikan terhadap kualitas audit pada Aparat Pengawas Internal Pemerintah di Inspektorat Daerah.

Dengan memperhatikan data hasil penelitian pada Inspektorat Provinsi Sulawesi Utara, dapat dikatakan bahwa implikasi pentingnya skeptisme profesional telah diterapkan. Dalam melakukan pemeriksaan auditor diperhadapkan pada situasi antara curiga dan percaya terhadap auditee. Tetapi auditor profesional tidak akan pernah berpikir bahwa auditee tidak jujur tapi auditor juga tidak dapat mengasumsikan bahwa auditee sepenuhnya jujur. Menolak statement tanpa ada pembuktian merupakan bukti bahwa auditor Inspektorat memiliki questioning mind yang tinggi atau pikiran selalu mepertanyakan sesuatu yang menjadi salah satu indikator dalam penelitian ini.

Dari hasil penelitian diperoleh bukti empirik bahwa auditor memahami betul bahkan secara profesional mampu bersikap skeptis dalam melakukan tugas. Dengan demikian dapatlah disimpulkan bahwa skeptisme profesional berpengaruh signifikan positif terhadap kualitas pemeriksaan. Sehingga semakin tinggi skeptisme profesional maka semakin baik juga kualitas pemeriksaan Inspektorat Provinsi Sulawesi Utara.

\section{Pengaruh Kompetensi Terhadap Kualitas Pemeriksaan}

Hasil pengujian statistik menunjukkan bahwa kompetensi tidak signifikan dan tidak menunjukan pengaruh terhadap kualitas pemeriksaan.

Hasil penelitian ini tidak konsisten dengan penelitian yang dilakukan Darayasa dan Wisadha (2016) bahwa kompetensi berpengaruh signifikan positif pada kualitas audit. Auditor yang berpendidikan tinggi akan mempunyai pandangan yang lebih luas mengenai berbagai hal. Sejalan dengan hasil penelitian ini adalah penelitian Riduwan, Suryono (2013) yang mengambil polulasi Inspektorat Kabupaten Gresik, Kabupaten Sidoarjo dan Kota Surabaya dan secara empirik membuktikan bahwa tidak ada pengaruh signifikan antara kompetensi terhadap kualitas audit.

Yang menjadi dasar pengukuran kompetensi dalam penelitian ini adalah Peraturan Kepala BPKP nomor 211 tahun 2010 tentang Standar Kompetensi Auditor. Standar ini menjelaskan ukuran kemampuan minimal yang harus dimiliki auditor yang mencakup aspek pengetahuan (knowledge), ketrampilan/keahlian (skill), dan sikap prilaku (attitude) untuk dapat melakukan tugas-tugas dalam jabatan fungsional auditor dengan hasil baik.

Memang dapat dipahami mengapa kompetensi tidak signifikan berpengaruh , karena aparat inspektorat tidak semuanya memiliki latar belakang pendidikan akuntansi atau auditor. Aparat inspektorat terdiri dari berbagai latar belakang ilmu, karena memang sebagai pengawas internal diharuskan melakukan pengawasan secara komprehensif. Untuk itu selain mengawasi bidang keuangan, aparat inspektorat dituntut untuk melakukan pengawasan di bidang kepegawaian, bidang pembangunan, dan bidang lain yang menunjang pembangunan daerah. 
Simpulan dari penelitian ini bahwa kompetensi tidak berpengaruh terhadap kualitas pemeriksaan Inspektorat Provinsi Sulawesi Utara. Artinya kompetensi auditor yang rendah akan berdampak pada rendahnya kualitas audit yang dihasilkan.

\section{Pengaruh Independensi dengan kualitas pemeriksaan}

Hasil pengujian statistik menunjukkan bahwa independensi berpengaruh signifikan dan positif terhadap kualitas pemeriksaan.

Hasil pengujian hipotesis ini sejalan dengan pendapat De Angelo (1981) bahwa kemungkinan dimana auditor akan melaporkan salah saji tergantung pada independensi auditor. Namun demkian, hasil penelitian ini tidak sejalan dengan Samelson,et.al,(2006) yang menyimpulkan bahwa independensi tidak mempunyai hubungan dengan kualitas audit. Arens $d k k$. (2004) menyatakan nilai auditing sangat bergantung pada persepsi publik akan independensi yang dimiliki auditor.

Memperhatikan indikator-indikator yang dijadikan pengukuran dalam penelitian ini, auditor Inspektorat Provinsi Sulawesi Utara terbukti sudah sangat memahami bahwa bersikap objektif dan netral, jujur dan menghindari konflik kepentingan, serta tidak kompromi dengan hasil yang di dapat dalam pemeriksaan, merupakan tindakan sangat tepat yang harus dilakukan untuk medapatkan hasil audit yang berkualitas. Disamping itu, adanya tekanan atau gangguan dari dalam diri auditor maupun dari luar yang sangat berpotensi untuk berperilaku tidak jujur, tidak menghambat aparat pengawas untuk tidak bersikap independen.

Penelitian yang tidak mendukung hasil ini adalah penelitian effendy (2010) pada Inspektorat Kota Gorontalo yang menunjukan independensi auditor tidak signifikan terhadap kualitas audit disebabkan aparat inspektorat masih terpengaruh dengan penentu kebijakan yang sering melakukan mutasi pegawai antar SKPD.

Dari hasil penelitian ini diperoleh bukti empirik bahwa auditor Inspektorat Provinsi memahami betul bahkan secara profesional mampu bersikap independen dalam melakukan tugas. Dengan demikian dapatlah disimpulkan bahwa independensi berpengaruh signifikan positif terhadap kualitas audit. Sehingga semakin tinggi independensi maka semakin baik juga kualitas pemeriksaan pada Inspektorat Provinsi Sulawesi Utara.

\section{Pengaruh Kepatuhan Pada Kode Etik Terhadap Kualitas Pemeriksaan}

Hasil pengujian statistik menunjukkan bahwa kepatuhan pada kode etik berpengaruh signifikan dan positif terhadap kualitas pemeriksaan.

Hasil ini sejalan dengan penelitian Ananda, (2014) yang menemukan data empiris bahwa kepatuhan pada kode etik berpengaruh signifikan positif terhadap kualitas audit. Artinya, semakin tinggi kepatuhan pada kode etik maka akan semakin baik pula kualitas audit pemerintahan. Demikian pula dengan penelitian Lubis, (2009) yang membuktikan pengaruh kepatuhan pada kode etik terhadap kualitas auditor adalah positif dan signifikan.

Adapun indikator yang dijadikan ukuran menilai kepatuhan kode etik berdasarkan prinsip etika yang diterbitkan oleh Asosiasi Auditor Intern Pemerintah Indonesia (AAIPI), yang mengatur perilaku auditor intern pemerintah berasas prinsip Intergritas, Objektivitas, Kerahasiaan, Kompetensi, Akuntabel dan Perilaku Profesional. Hasil penelitian membuktikan bahwa auditor inspektorat mampu menerapkan dan menegakkan prinsip-prinsip etika dalam menjalankan tugas pengawasan dalam peningkatan kualitas audit.

Disamping itu, indikator lain dalam pengukuran variabel ini didasarkan pada Peraturan Menteri Dalam Negeri Nomor 28 tahun 2007 tentang Norma Pengawasan dan Kode etik Pejabat Pengawas Pemerintah, yang mengatur sikap auditor dalam hubungan dengan lembaga dan organisasinya, auditor dengan sesama pejabat pengawas, auditor dengan pihak yang diawasi, serta auditor dan masyarakat. Hasil penelitian menggambarkan bahwa auditor inspektorat memahami bahwa sebagai aparat pengawas harus memiliki sikap patuh pada kode etik, karena dengan menerapkan sikap tersebut maka auditor akan mampu menjaga perilaku etisnya dan dapat 
memenuhi prinsip-prinsip kerja yang akuntabel dengan kinerja yang optimal dalam pelaksanaan audit.

Dengan demikian dapat dikatakan bahwa sikap patuh pada kode etik yang ditunjukkan oleh aparat pengawas Inspektorat Provinsi Sulawesi Utara, mampu membawa pengaruh besar dalam peningkatan kualitas pemeriksaan. Dan simpulan dari penelitian ini bahwa kepatuhan pada kode etik berpengaruh signifikan positif terhadap kualitas pemeriksaan.

\section{Pengaruh Skeptisisme Profesional yang dimoderasi Kepatuhan Pada Kode Etik Terhadap Kualitas Pemeriksaan}

Hasil uji statistik menunjukan bahwa interaksi skeptisisme profesional dan kepatuhan pada kode etik (X1.X4) dengan nilai signifikan 0,871 diatas tingkat signifikansi 0,05 dan perhitungan nilai thitung sebesar -0,163 lebih kecil dibanding tabel 1,997. Hasil tidak signifikan yang ditunjukan oleh variabel moderasi (interaksi skeptisisme profesional dan kepatuhan pada kode etik) membuktikan bahwa variabel ini bukan variabel moderating. Kondisi ini tergambar dari hasil penelitian pada model 2 bahwa skeptisisme profesional menjadi tidak signifikan dengan nilai sig 0,164 setelah adanya variabel / faktor moderasi, demikian juga kepatuhan pada kode etik menjadi tidak signifikan dengan nilai sig 0,333.

Berdasarkan hasil pengujian statistik seperti yang telah dijelaskan sebelumnya terbukti interaksi skeptisisme profesional dan kepatuhan pada kode etik bukan merupakan variabel moderat, sehingga penelitian ini menyimpulkan bahwa secara parsial skeptisisme profesional tidak berpengaruh terhadap kualitas pemeriksaan yang dimoderasi oleh kepatuhan pada kode etik.

\section{Pengaruh Kompetensi yang dimoderasi Kepatuhan Pada Kode Etik Terhadap Kualitas Pemeriksaan}

Hasil uji statistik menunjukan bahwa interaksi kompetensi dan kepatuhan pada kode etik (X2.X4) dengan nilai signifikan 0,827 melebihi tingkat signifikansi 0,05 dan perhitungan nilai thitung sebesar 0,219 lebih kecil dibanding ttabel 1,997. Hasil tidak signifikan yang ditunjukan oleh faktor moderasi (interaksi kompetensi dan kepatuhan pada kode etik) membuktikan bahwa variabel ini bukan variabel moderating. Kondisi ini tergambar dari hasil penelitian pada model 2 bahwa kompetensi dengan nilai sig 0,256 tidak signifikan setelah adanya variabel / faktor moderasi, demikian juga kepatuhan pada kode etik dengan nilai signifikan 0,333.

Berdasarkan hasil pengujian statistik seperti yang telah dijelaskan sebelumnya terbukti interaksi kompetensi dan kepatuhan pada kode etik bukan merupakan variabel moderat, sehingga penelitian ini menyimpulkan bahwa secara parsial kompetensi tidak berpengaruh terhadap kualitas pemeriksaan yang dimoderasi oleh kepatuhan pada kode etik.

\section{Pengaruh Independensi yang dimoderasi Kepatuhan Pada Kode Etik Terhadap Kualitas Pemeriksaan}

Hasil uji statistik menunjukan bahwa interaksi independensi dan kepatuhan pada kode etik (X3.X4) dengan nilai signifikan 0,707 telah melebihi tingkat signifikansi sebesar 0,05 dan perhitungan nilai thitung sebesar $-0,378$ lebih kecil dibanding ttabel 1,997. Hasil tidak signifikan yang ditunjukan oleh faktor moderasi ini (interaksi independensi dan kepatuhan pada kode etik) membuktikan bahwa variabel ini bukan variabel moderating. Kondisi ini juga tergambar dari hasil penelitian pada model 2 bahwa independensi dengan nilai sig 0,341 menjadi tidak signifikan setelah adanya variabel / faktor moderasi, demikian juga kepatuhan pada kode etik menjadi tidak signifikan dengan nilai sig 0,333 .

Berdasarkan hasil pengujian statistik seperti yang telah dijelaskan sebelumnya terbukti interaksi independensi dan kepatuhan pada kode etik bukan merupakan variabel moderat, sehingga penelitian ini menyimpulkan bahwa secara parsial independensi tidak berpengaruh terhadap kualitas pemeriksaan yang dimoderasi oleh kepatuhan pada kode etik.

Tidak signifikan dalam pengujian moderasi memang merupakan permasalahan yang sering muncul. Bahkan walaupun nilainya signifikan tapi tidak membawa pengaruh yang besar karena 
memang nilai signifikansinya sangat kecil. Dari pernyataan Marsh, et.al, 2013 dalam The Oxford Handbook Of Quantitative Methods II, page 361 menyatakan:

Many theoretical models explicitly posit interaction effects. Nevertheless, particularly in applied research, even interactions hypothesized on the basis of strong theory and good intuition are typically small, nonsignificant, or not easily replicated. Part of the problem is that applied researchers often do not know how to test interaction effects, as statistical best practice is still evolving and often not followed. Also, tests of interactions frequently lack power so that meaningfully large interaction effects are not statistically significant.

\subsection{Kesimpulan}

\section{KESIMPULAN DAN SARAN}

Berdasarkan hasil penelitian maka dapat diambil kesimpulan sebagai berikut :

1. Skeptisisme profesional berpengaruh signifikan positif terhadap kualitas pemeriksaan.

2. Kompetensi tidak berpengaruh terhadap kualitas pemeriksaan.

3. Independensi berpengaruh signifikan positif terhadap kualitas pemeriksaan,

4. Kepatuhan pada kode etik berpengaruh signifikan positif terhadap kualitas pemeriksaan.

5. Skeptisisme profesional yang dimoderasi oleh kepatuhan pada kode etik tidak berpengaruh terhadap kualitas pemeriksaan

6. Kompetensi yang dimoderasi oleh kepatuhan pada kode etik tidak berpengaruh terhadap kualitas pemeriksaan.

7. Independensi yang dimoderasi kepatuhan pada kode etik tidak berpengaruh terhadap kualitas pemeriksaan.

\subsection{Implikasi}

Implikasi dari penelitian ini adalah aparat pengawasan Inspektorat Provinsi Sulawesi Utara. Peneliti juga mengajurkan kepada pimpinan berwenang untuk lebih memberi perhatian terhadap kompetensi dalam menunjang pengawasan. Kompetensi harus terus ditingkatkan dengan mengikutsertakan auditor dalam pendidikan dan pelatihan, kursus-kursus, serta pendidikan profesi yang berkelanjutan untuk meningkatkan kompetensinya . Disamping itu pelatihan di kantor sendiri akan lebih efekfif dalam meningkatkan kompetensi auditor.

Auditor internal pada Inspektorat Provinsi Sulawesi Utara diharapkan untuk mempertahankan skeptisisme yang tinggi, menerapkan independensi yang tinggi dan patuh pada kode etik dalam menjalankan tugas dan tanggung jawannya. Karena tuntutan profesional auditor internal sebagai aparatur yang mengawasi pengelolaan keuangan adalah haparan masyarakat untuk tercapainya pemerintahan yang baik.

\subsection{Saran}

Adapun saran yang dapat diberikan berdasarkan hasil penelitian yang didapat dalam penelitian ini adalah sebagai berikut:

1. Bagi pengawas internal menjaga dan mempertahankan skeptisisme profesional yang tinggi dalam melaksanakan audit

2. Sebaiknya seorang auditor meningkatkan kompetensinya dengan mengikuti pendidikan dan pelatihan, kursus-kursus teknis serta pelatihan kantor

3. Independensi yang tinggi haruslah dipertahankan oleh seorang auditor internal,

4. Auditor harus meyakini bahwa prinsip-prinsip dalam kode etik merupakan bagian penting dari profesionalisme dan menjadi pedoman dalam menjalankan

5. Untuk meminimalkan bias akibat sedikitnya responden, maka penelitian sebaiknya dilakukan dalam cakupan yang lebih luas dengan menambah dan memperluas wilayah dan menambahkan teknik pengumpulan data

6. Meneliti pengaruh variabel-variabel lain yang belum termasuk dalam model regresi pada penelitian ini. 


\section{DAFTAR PUSTAKA}

Arens.A, R.Elder, M.Beasley. 2014. Auditing dan Jasa Assurance Pendekatan Terintegrasi Edisi 15 Jilid 1. Penerbit Erlangga.

Ananda, 2014. Pengaruh Skeptisme Profesional, Kepatuhan Pada Kode Etik Dan Independensi Terhadap Kualitas Audit. (Studi Empiris pada BPKP perwakilan Sumatera Utara). Skripsi Fakultas Ekonomi Universitas Negeri Padang.

Adrian Arfin. 2013. Pengaruh Skeptisme Profesional, Etika, Pengalaman, Dan Keahlian Audit Terhadap Ketepatan Pemberian Opini Oleh Auditor (Studi BPK RI Perwakilan Prov. Riau)

Alim, Hapsari, Purwanti, 2007. Pengaruh Kompetensi Dan Independensi Terhadap Kualitas Audit Dengan Etika Auditor Sebagai Variabel Moderas. Simposium Nasional Akuntansi X Makasar.

Asosiasi Auditor Intern Pemerintah Indonesia (AAIPI) 2014, Kode Etik Auditor Intern Pemerintah. BPKP, Pusat Diklat Pengawasan BPKP, Modul 2008.

Boynton Johnson Kell, 2003. Modern Auditing. Penerbit Erlangga, Jakarta, 2003.

DeAngelo, L. E. 1981a. Auditor Size and Audit Quality. Journal of Accounting and Economics 3

Darayasa, Wisadha, 2016. Etika Auditor sebagai Pemoderasi Pengaruh Kompetensi dan Independensi pada Kualitas Audit di Kota Denpasar. E-Jurnal Ak. Universitas Udayana Vol.15.1. April (2016): 142-170.

Efendy. 2010. Pengaruh Kompetensi, Independensi dan Motivasi auditor terhadap Kualitas Audit Inspektorat dalam Pengawasan Keuangan Daerah (Studi Empiris pada Pemerintah Kota Gorontalo). Tesis Magister Sains Akuntansi Universitas Diponegoro.

Fa'ati. 2014. Pengaruh Tipe Kepribadian Dan Kompetensi Auditor Terhadap Skeptisme Profesional Auditor (Studi Empiris Pada Kap Kota Semarang). Accounting Analysis Journal AAJ 3

Financial Reporting Council, 2010. Auditor Scepticism : Raising The Bar. The Auditing, Practices Board. August 2010.

Festinger Leon .1957. A Theory Cognitive Dissonance. California : Stanford Univesity Press.

Ghozali, I. 2006. Aplikasi Analisis Multivariat dengan Program SPSS. Edisi 3. BP Undip.

Semarang.

Hayes. Andrew.F. 2005. Statistical Methods for Communication Science. The Ohio State University. Lawrence Erlbaum Associates, publishers. Mahwah, New Jersey.

Hasanah Sri, 2010. Pengaruh penerapan aturan Etika, Pengalaman dan Skeptisme profesional auditor terhadap pendeteksian kecurangan. (Studi empiris beberapa kantor akuntan publik DKI Jakarta). FEB Universitas Islam Negeri Syarif Hidayatullah Jakarta.

http//e-journal.uajy.ac.id. Skeptisisme Profesional dalam Auditing. diunduh tanggal 3 Februari 2016.

Institut Akuntan Publik Indonesia (IAPI), 2011. Standar Profesional Akuntan Publik.

Jensen, Meckling, 1976. Theory of the Firm: Managerial Behavior, Agency Costs and Ownership

Structure. Journal of Financial Economics, October, 1976, V. 3, No. 4, pp. 305-360.

Khairunnisa, Nor ,Octaviani. 2015. Pengaruh kompetensi dan independensi terhadap kualitas audit: etika auditor sebagai variabel pemoderasi (studi empiris pada bpkp perwakilan kalimantan selatan). Universitas Lambung Mangkurat. Konferensi Regional Akuntansi II 2015 (Malang).

Kushasyandita, 2012. Pengaruh Pengalaman, Keahlian, Situasi Audit, Etika Dan Gender Terhadap Ketepatan Pemberian Opini Auditor Melalui skeptisisme Profesional Auditor.

Kalau Ali Amin. 2013. Pengaruh Kompetensi, Independensi Dan Skeptisisme Profesional Auditor Internal Terhadap Kualitas Audit (Survey Persepsi Auditor Inspektorat Kota Ambon). Cita Ekonomika Jurnal Ekonomi Volume VII, No. 2, Desember 2013.

Lampiran Peraturan Men-PAN Nomor : PER/05/M.PAN/03/2008 Tanggal : 31 Maret 2008 tentang Standar Audit Aparat Pengawas Internal Pemerintah.

Lubis Haslinda. 2009. Pengaruh Keahlian, Independensi, Kecermatan Profesional dan Kepatuhan pa 
Etik Terhadap Kualitas Auditor Pada Inspektorat Provinsi Sumatera Utara. Tesis Magistegis Ilmu Akuntansi Universitas Sumatera Utara, Tidak Dipublikasikan.

Liana Lie, 2009. Penggunaan MRA dengan SPSS untuk menguji Pengaruh Variabel Moderating Hubungan antara Variabel Independen dan Variabel Dependen. Jurnal Teknologi Informasi D] Volume XVI no 2, Juli 2009.

Mardiasmo. 2005. Akuntansi Sektor Publik Edisi 2. Penerbit Andi. Yogyakarta

Marsellia, Meiden, Hermawan. 2012. Pengaruh Kompetensi dan Independensi Terhadap Kualitas Audit Dengan Etika Auditor Sebagai Variabel Moderator.

Mufidah. Analisis Pengaruh Independensi, Obyektifitas, Integritas, Kompetensi, Pengalaman Kerja Dan Skeptisisme Profesional Terhadap Kualitas Hasil Pemeriksaan Di Lingkungan Inspektorat Provinsi Jambi. Jurnal Akuntansi dan Keuangan Unja volume 2 tahun 2015.

Magnis - Suseno, 1997. 13 Tokoh Etika - Sejak Zaman Yunani sampai Abad ke-19. Cetakan ke-7, Penerbit Karnisius.

Maritha-try.blogspot.co.id / 2014. Etika dalam Auditing. diunduh tanggal 20 Januari 2016.

Marsh.Herbert. W , Kit-Tai Hau, ZhonglinWen, Benjamin Nagengast, and Alexandre J.S. Morin.

The Oxford Handbook Of Quantitative Methods II, Chapter 17, Page 361 - 386.

Nandari dan Latrini, 2015. Pengaruh Sikap Skeptis, Independensi, Penerapan Kode Etik, Dan Akuntabilitas Terhadap Kualitas Audit. E-jurnal Akuntansi Universitas Udayana 10.1 (2015) : 164-181.

Oktarini, Ramantha, 2016. Pengaruh Pengalaman kerja dan Kepatuhan terhadap Kode Etik pada Kualitas Audit melalui Skeptisisme Profesional Auditor. E-jurnal Universitas Udayana Vol. 15 April $2016:$ 475-783.

Priyansari, Natalistyo, 2015. Pengaruh Kompetensi, Independensi dan Etika Auditor terhadap Kualitas Audit (Studi empiris pada auditor pemerintah di BPKP Perwakilan Jawa Tengah).

Perdany dan Sri Suranta, 2013. Pengaruh Kompetensi Dan Independensi Auditor Terhadap Kualitas Audit Investigatif Pada Kantor Perwakilan Bpk-Ri Yogyakarta. Fakultas Ekonomi Universitas Sebelas Maret. Jurnal Akuntansi dan Bisnis Vol 14 no.1 Februari 2013.

Poluan Margie, 2015. Pengaruh Locus of Control, Self Esteem, Equity Sensivity Auditor Internal terhadap Kualitas Audit dengan Gender sebagai Variabel Mediasi pada Kantor Inspektorat Provinsi Sulawesi Utara. Fakultas Ekonomi dan Bisnis Universitas Sam Ratulangi Manado.

Peraturan Pemerintah Nomor 60 Tahun 2008 tentang Sistem Pengendalian Intern Pemerintah.

Peraturan Menteri Dalam Negeri Nomor 64 tahun 2007 tentang Pedoman Teknis Organisasi dan Tata Kerja Inspektorat Provinsi dan Kabupaten/kota.

Peraturan Menteri dalam Negeri Nomor 28 tahun 2007 Tentang Norma Pengawasan dan Kode Etik Pejabat Pengawas Pemerintah.

Peraturan Men-PAN Nomor : PER/05/M.PAN/03/2008 Tanggal : 31 Maret 2008 tentang Standar Audit Aparat Pengawas Internal Pemerintah.

Peraturan Gubernur Nomor 63 Tahun 2008 tentang Uraian Tugas Inspektorat Provinsi Sulut Peraturan Pemerintah Nomor 8 tahun 2006 tentang Pelaporan Keuangan dan Kinerja Instansi Pemerintah.

Peraturan BPK-RI Nomor 1 tahun 2007 tentang Standar Pemeriksaan Keuangan Negara.

Peraturan Kepala BPKP nomor 211 tahun 2010 tentang Standar Kompetensi Auditor.

Rahayu Alkam. 2013. Pengaruh Moral Reasoning Auditor Pemerintah Terhadap Kualitas Audit.

Skripsi Jurusan Akuntansi Fakultas Ekonomi dan Bisnis Universitas Hasanudin Makasar.

Riduwan dan Suryono. 2013. Pengaruh pengalaman kerja, independensi, dan Kompetensi terhadap kualitas audit: etika auditor sebagai Variabel pemoderasi. Jurnal Ilmu dan Riset Akuntansi Volume 1 Nomor 2, Maret 2013.

Sugiyono, cetakan kedua 2015. Metode Penelitian Pendidikan. Penerbit Alfabeta Bandung.

Sukrisno Agoes dan I Cenik Ardana . 2009. Etika Bisnis dan Profesi . Jakarta: Salemba Empat.

Safitri, Sularso , Restianto (2013). Analisis faktor-faktor yang mempengaruhi kualitas audit dengan reward sebagai variabel pemoderasi. Jurnal \& Proceeding Universitas Jenderal Soedirman Vol 3 no. 1 tahun 2013. 
Suraida Ida , 2005. Pengaruh Etika, Kompetensi, Pengalaman Audit dan Resiko Audit terhadap Skeptisisme Profesional Auditor dan ketepatan Pemberian Opini Akuntan Publik. Jurnal Ilmiah volume 7 no.3, November 2005.

SPAP SA 200. Tujuan Keseluruhan Auditor Independen dan Pelaksanaan Audit Berdasarkan Standar Audit. 2011. Ikatan Akuntan Publik Indonesia.

Sukrisno Agus dan Ardana. 2009. Etika Bisnis dan Profesi. Salemba Empat, Jakarta. 